\title{
PROBLEMATIKA GUGUS TUGAS DALAM UPAYA PENCEGAHAN DAN PENANGANAN TINDAK PIDANA PERDAGANGAN ORANG (HUMAN TRAFFICKING) ${ }^{1}$
}

\author{
Meysasi Kirana Resa*, Nyoman Serikat Putra Jaya \\ Fakultas Hukum Universitas Diponegoro \\ Jl. Prof. Soedarto, S.H. Tembalang, Kota Semarang, Kode Pos 50275 \\ meysasi.kiranaresa@gmail.com
}

\begin{abstract}
Human trafficking cases involving minors in Semarang City have experienced a sharp increase in the past year. This indicates that the role of the Task Force is still not optimal in preventing and handling cases of trafficking in persons in Semarang City. This study aims to identify and describe the problems of the task force in making efforts to prevent and handle the criminal act of trafficking in persons in the city of Semarang. With the normative juridical research method, the results of this study are: the problems of the task force can be viewed from two factors, namely internal factors and external factors. In terms of internal factors, the problem of the task force is that it is closely related to the agency or institution itself, while in terms of external factors, the problem of the task force is related to external parties such as such as victims and traffickers themselves.
\end{abstract}

Keywords: Problematics; Task Force; Human Trafficking.

\begin{abstract}
Abstrak
Kasus perdagangan manusia yang melibatkan anak di bawah umur di Kota Semarang mengalami peningkatan tajam dalam satu tahun terakhir. Hal ini mengindikasikan bahwa peran Gugus Tugas masih belum optimal dalam melakukan pencegahan dan penanganan kasus perdagangan orang di Kota Semarang. Penelitian ini bertujuan untuk mengetahui dan mendeskripsikan problematika gugus tugas dalam melakukan upaya pencegahan dan penanganan tindak pidana perdagangan orang di Kota Semarang. Dengan metode penelitian yuridis normatif, hasil dari penelitian ini yaitu: problematika gugus tugas dapat ditinjau dari dua faktor yaitu faktor internal dan faktor eksternal. Ditinjau dari faktor internal, problematika gugus tugas ialah berkaitan erat dengan instansi atau lembaga itu sendiri, sedangkan ditinjau dari faktor eksternal, problematika gugus tugas ialah berkaitan dengan pihak-pihak luar seperti misalnya dari korban maupun dari pelaku TPPO itu sendiri.
\end{abstract}

Kata Kunci: Problematika; Gugus Tugas; Perdagangan Orang.

\footnotetext{
${ }^{1}$ Artikel hasil penelitian mandiri yang dilakukan oleh Penulis pada tahun 2020.
} 


\section{A. Pendahuluan}

Perdagangan orang telah diatur dalam sebuah Undang-Undang yakni UndangUndang Nomor 21 Tahun 2007 tentang Pemberantasan Tindak Pidana Perdagangan Orang. Undang-Undang ini kemudian dilaksanakan melalui Keputusan Presiden Republik Indonesia Nomor 88 Tahun 2002 tentang Rencana Aksi Nasional Penghapusan Perdagangan Perempuan dan Anak (RAN P3A). Selain peraturan perundang-undangan tersebut, Pemerintah Republik Indonesia juga telah mengeluarkan undang-undang lain yang terkait pemberantasan perdagangan perempuan dan anak yaitu Undang-Undang Nomor 13 Tahun 2005 tentang Ketenagakerjaan dan Undang-Undang Nomor 39 Tahun 2004 tentang Penempatan dan Perlindungan Tenaga Kerja di Luar Negeri (Erdianto, 2013).

Di Indonesia, perdagangan perempuan dan anak-anak marak terjadi di daerah perbatasan dengan negara tetangga, seperti misalnya perbatasan dengan Singapura, Malaysia, atau Brunei Darussalam, meski juga tidak sedikit terjadi di daerah yang berdekatan dengan wilayah kota besar seperti Jakarta, Medan, Surabaya, maupun Semarang.(Hanim \& Prakoso, 2015) Dinas Pemberdayaan Perempuan, Perlindungan Anak, Pengendalian Penduduk, dan Keluarga Berencana (DP3AKB) Jateng mencatat selama 2018 ada 48 kasus perdagangan anak yang terjadi di Jateng. Jumlah ini naik lebih dari dua kali lipat atau sekitar 196\% dibanding tahun 2017 lalu, yang hanya 17 kasus. Dari jumlah sebanyak itu, Kota Semarang menyumbang kasus terbanyak. Dari 48 kasus perdagangan anak di Jateng, 47 kasus di antaranya berasal dari Kota Semarang. Padahal pada 2017 lalu, dari 17 kasus perdagangan anak yang ditemukan di Jateng, hanya tiga yang terjadi di Kota Semarang (Saputra, 2019). Guna menunjang terlaksananya penyelenggaraan perlindungan kepada perempuan dan anak dari tindak kekerasan di Kota Semarang maka Walikota membentuk Gugus Tugas Tindak Perdagangan Orang yang termaktub dalam Pasal 1 angka 18 Peraturan Daerah Kota Semarang Nomor 5 Tahun 2016 tentang Perlindungan Perempuan dan Anak Dari Tindak Kekerasan.

Istilah problema/problematika berasal dari bahasa Inggris yaitu "problematic" yang artinya persoalan atau masalah. Sedangkan dalam Kamus Besar Bahasa Indonesia, persoalan atau masalah berarti sesuatu yg harus diselesaikan atau harus dicarikan jalan keluarnya; persoalan berarti perbahasan; perdebatan; perbincangan; hal-hal; perkara; masalah; problem (Pusat Bahasa \& Departemen Pendidikan Nasional, 2008). Adapun pengertian masalah itu sendiri adalah suatu kendala atau persoalan yang harus dipecahkan, dengan kata lain masalah merupakan kesenjangan antara kenyataan dengan sesuatu yang diharapkan. Problematika gugus tugas adalah segala sesuatu yang menjadi kendala bagi gugus tugas untuk melaksanakan tugas dan fungsinya agar persoalan-persoalan kasus perdagangan orang dapat dipecahkan.

Berdasarkan Undang-Undang Nomor 21 Tahun 2007 tentang Pemberantasan Tindak Pidana Perdagangan Orang (PTPPO) definisi perdagangan orang adalah:

Tindakan perekrutan, pengangkutan, penampungan, pengiriman, pemindahan, atau penerimaan seseorang dengan ancaman kekerasan, penggunaan kekerasan, penculikan, penyekapan, pemalsuan, penipuan, penyalahgunaan kekuasaan atau posisi rentan, penjeratan utang atau memberi bayaran atau manfaat, sehingga memperoleh persetujuan dari orang yang memegang kendali atas orang lain tersebut, baik yang dilakukan di dalam negara maupun antar negara, untuk tujuan eksploitasi atau mengakibatkan orang tereksploitasi. Eksploitasi mencakup eksploitasi dari prostitusi orang lain atau bentuk eksploitasi seksual, kerja atau pelayanan paksa, perbudakan atau praktik serupa perbudakan, penghambaan atau pemindahan organ tubuh. Pada bulan Juni 2010 Protokol Perdagangan telah 
ditandatangani oleh 117 negara dan 137 pihak.

Okky Chahyo Nugroho dalam jurnal dengan judul: Tanggung Jawab Negara Dalam Penanganan Tindak Pidana Perdagangan Orang (State's Responsibility in Mitigation of Human Trafficking Crime) menyimpulkan bahwa Gugus Tugas ini belum optimal karena hanya bersifat koordinatif dan adanya praktek sistem penempatan TKI yang tidak memberikan perlindungan sejak dini sehingga bertentangan dengan upaya pencegahan perdagangan orang (Nugroho, 2018). Sama halnya dengan Okky, Abdul Rahman Prakoso dan Putri Ayu Nurmalinda dalam jurnal dengan judul Kebijakan Hukum Terhadap Tindak Pidana Perdagangan Orang juga berpendapat bahwa Implementasi pencegahan perdagangan orang dalam bentuk penegakan hukum belum optimal seperti masih sedikit pelaku perdagangan orang yang tertangkap, dan minimnya oknum aparat yang berhasil ditahan, serta putusan pidana terhadap pelaku yang ringan sehingga tidak memberikan efek jera kepada pelaku dan masyarakat (Prakoso, Abdul Rahman, \& Nurmalinda, 2018). Gambaran mengenai trafficking juga dikemukakan oleh Indrawati dalam jurnal dengan judul Trafficking Kejahatan Terhadap Perempuan dan Anak-Anak. Berdasarkan hasil penelitian diperoleh gambaran tentang trafficking yang dapat disimpulkan sebagai berikut: 1) Penanganan korban trafficking selain menggunakan payung hukum Undang Undang Nomor 21 Tahun 2007 tentang Tindak Pidana Perdagangan Orang, dalam implementasinya juga perlu melibatkan peran aparat penegak hukum dan Departeman Sosial untuk mengupayakan pembinaan terhadap korban. 2) Pemberantasan trafficking merupakan tanggung jawab bersama, baik pemerintah maupun masyarakat. Peran serta masyarakat diharapkan dapat mencegah meluasnya trafficking di suatu daerah. 3) Menghimbau pemerintah dan pihak swasta untuk membuka lapangan kerja dan memberi penyuluhan intensif tentang bahaya trafficking serta akibat-akibatnya pada perempuan dan anak, sehingga tidak tergiur bekerja di tempat maksiat (Indrawati, 2015).

Para korban perdagangan orang seringkali tidak sadar bahwa mereka merupakan korban perdagangan orang, hal ini tentunya disebabkan bahwa "trafficking" dikemas sedemikian rupa sehingga para korban tidak menyadarinya. Louise Shelley dalam jurnal dengan judul Human Trafficking: A Global Perspective menyimpulkan bahwa perbudakan kulit putih di awal abad ke-20 dilakukan oleh aktor-aktor non-negara, seperti halnya 80 persen dari perdagangan manusia hari ini menurut data ILO yang dikutip sebelumnya (Shelley, 2010). Seperti hari ini, perbudakan kulit putih melibatkan pergerakan korban jarak jauh melintasi benua dan lautan. Para korban ini sering tertipu tentang masa depan mereka di negara tujuan mereka. Anil Kumar, Jaya. Dalam jurnal dengan judul Fte Impact of Human Trafficking in ASEAN: Singapore as a case-study (Anil Kumar, 2018). Berdasarkan hasil penelitian, dapat disimpulkan bahwa TIP (Trafficking in Persons) lazim di Singapura (Han, 2014). Pada tahun 2010, pemerintah Singapura membentuk Satuan Tugas, yang membentuk Rencana Aksi Nasional (NPA) untuk memerangi TIP. NPA mengidentifikasi empat cara di mana Singapura akan meningkatkan pertempurannya melawan TIP: (1) pencegahan TIP; (2) penuntutan terhadap pelanggar; (3) perlindungan korban TIP; dan (4) kemitraan dengan negaranegara lain, organisasi non-pemerintah, akademisi, dan sektor swasta, untuk memerangi TIP. (Affairs, 2012)

Indonesia menempati posisi ketiga di dunia dengan angka kasus TPPO tertinggi yang mana pada tahun 2012, isu TPPO mulai masuk ke Indonesia. TPPO bisa terjadi di mana saja dan melibatkan kelompok rentan. Hal ini menjadi salah satu indikasi bahwa peran Gugus Tugas masih belum optimal dalam melakukan pencegahan dan penanganan kasus perdagangan orang. Oleh karena itu, 
penelitian ini penting dilakukan untuk mengetahui dan mendeskripsikan hal apa saja yang menjadi kendala (problematika) bagi gugus tugas dalam melakukan upaya pencegahan dan penanganan tindak pidana perdagangan orang ditinjau dari faktor internal dan eksternal yang mempengaruhi sehingga dapat menjadi kajian bersama terkait regulasi mengenai kasus kemanusiaan khususnya perlindungan perempuan dan anak di masa yang akan datang.

Kasus perdagangan orang (human trafficking) bukan merupakan kasus yang baru, penelitian mengenai kasus perdagangan orang hingga saat ini masih menjadi kasus yang menarik untuk dibahas dan diteliti. Human trafficking menjadi sangat penting untuk dibahas karena mendapat perhatian dikalangan masyarakat terhadap nilai keamanan serta kemanusiaan bukan hanya bagi masyarakat Indonesia, melainkan juga bagi masyarakat dunia. Perdagangan orang adalah bentuk modern dari perbudakan manusia dan merupakan salah satu bentuk perlakuan terburuk dari pelanggaran harkat dan martabat manusia. (Undang-Undang Nomor 21 Tahun 2007 tentang Pemberantasan Tindak Pidana Perdagangan Orang, 2007) Perbedaan dan uniknya penelitian ini dengan penelitian sebelumnya ialah penelitian sebelumnya berfokus pada kebijakan atau regulasi hukum maupun pemangku kepentingan mengenai tindak pidana perdagangan orang di tiap daerah, sedangkan pada penelitian ini akan membahas problematika dari suatu lembaga yakni gugus tugas yang memang memiliki peranan dalam mencegah maupun menangani kasus perdagangan orang, meninjau lebih dalam mengenai faktorfaktor apa saja yang menjadi kendala gugus tugas dalam menjalankan perannya ditinjau dari segi internal (dalam) dan dari segi eksternal (luar) sehingga dapat menemukan titik permasalahan dan dapat memberikan solusi yang tepat untuk mengatasi problematika tersebut.

\section{B. Metode Penelitian}

Metode pendekatan yang dipergunakan dalam penyusunan jurnal ini adalah penelitian yuridis empiris (metode penelitian sosiolegal), dan menggunakan metode berpikir deduktif. Singkatnya bahwa penelitian yuridis empiris ini menitikberatkan pada perilaku individu atau masyarakat dalam kaitannya dengan hukum (Ali, 2011). Dengan demikian objek yang dianalisis dengan pendekatan yang bersifat kualitatif adalah metode penelitian yang mengacu pada norma-norma hukum yang terdapat dalam peraturan perundangundangan (S. dan S. M. Soekanto, 2009). Penelitian ini menggunakan spesifikasi penelitian tipe deskriptif analitis yaitu menganalisis dan mengambil kesimpulan umum dari masalah yang dibahas mengenai Problematika Gugus Tugas dalam Upaya Pencegahan dan Penanganan Kasus Perdagangan Orang (Human Trafficking) agar menjadi kajian perbandingan untuk pembaharuan hukum pidana tentang pencegahan dan penanganan kasus perdagangan orang terhadap perempuan dan anak dalam peraturan perundang-undangan di masa yang akan datang.

Jenis sumber data dalam penelitian ini adalah data sekunder yang merupakan bahan utama dalam penelitian ini yang merupakan penelitian yuridis-empiris. Adapun bahanbahan hukum sekunder yang digunakan dalam penelitian ini dibagi menjadi tiga macam, yaitu bahan hukum primer, bahan hukum sekunder, dan bahan hukum tersier. Teknik pengumpulan data menggunakan teknik dokumentasi dan studi kepustakaan. Adapun sumber data dokumen diperoleh dari lapangan berupa buku, arsip, majalah bahkan dokumen perusahaan atau dokumen resmi yang berhubungan dengan fokus penelitian (S. dan S. M. Soekanto, 2009). Teknik dokumentasi adalah metode yang digunakan untuk mencari data mengenai halhal atau variabel yang berupa catatan transkrip, buku, surat kabar, prasasti, notulen surat, dan lain-lain (Arikunto, 2012). Dokumentasi digunakan untuk memperoleh data mengenai kasus-kasus perdagangan 
orang (Human Trafficking) yang pernah terjadi di Kota Semarang. Sedangkan, studi kepustakaan dilakukan dengan menggunakan serangkaian studi dokumentasi dengan cara mengumpulkan, membaca, mempelajari, membuat catatancatatan, dan kutipan- kutipan serta menelaah bahan-bahan pustaka yaitu berupa karya tulis dari para ahli yang tersusun dalam literatur dan peraturan perundang-undangan yang berlaku dan ada kaitanya dengan permasalahan yang sedang dibahas dalam penelitian. Dalam penelitian ini, data yang diperoleh disajikan secara kualitatif dengan menggunakan analisis deskriptif dan diolah dengan tiga tahapan yaitu editing, sistematisasi, dan interpretasi.

\section{Hasil dan Pembahasan}

1. Problematika Gugus Tugas dalam Upaya Pencegahan dan Penanganan Kasus Perdagangan Orang (Human Trafficking) Ditinjau dari Faktor Internal.

a. Koordinasi Antar-Instansi yang Belum Optimal

Koordinasi yang lemah antar instansi merupakan masalah yang klasik. Koordinasi adalah salah satu bentuk hubungan kerja yang memiliki karakteristik khusus, antara lain harus adanya integrasi serta sinkronisasi atau adanya keterpaduan, keharmonisan serta arah yang sama. Adanya beberapa instansi yang masih bersifat egosektoral antar lembaga yang berjalan sendiri-sendiri menjadi salah satu problematika gugus tugas dalam upaya pencegahan dan penanganan kasus perdagangan orang. Koordinasi antar instansi lembaga yang menjadi anggota gugus tugas tersebut dirasakan masih kurang. Hal ini antara lain ditandai dengan masih kurangnya sosialisasi dan advokasi mengenai UU TPPO, belum maksimalnya pelaksanaan pemberantasan
TPPO/anak, serta masih kurang maksimalnya mekanisme pelaporan dan evaluasi terkait pencegahan dan penanganan TPPO/anak. (Lembaga, 2011)

Koordinasi pemberantasan perdagangan anak tersebut, sudah tentu tidak hanya cukup melibatkan satu lembaga saja, akan tetapi harus melibatkan semua pemangku kepentingan yang ada di masyarakat, yaitu instansi-instansi pemerintah, LSM, organisasi kemasyarakatan yang tergabung dalam sebuah kemitraan. Hal ini sesuai dengan pasal 58 UndangUndang nomor 27 tahun 2007 tentang Tindak Pidana Perdagangan Orang (TPPO) jo Peraturan Pemerintah No. 9 Tahun 2008 Tentang Tata Cara Dan Mekanisme Pelayanan Terpadu Bagi Saksi Dan/Atau Korban Tindak Pidana Perdagangan Orang jo Peraturan Presiden No. 69 Tahun 2008 Tentang Gugus Tugas Pencegahan dan Penanganan Tindak Pidana Perdagangan Orang.

Terkait dengan koordinasi antar sektor (anggota gugus tugas) dari pusat sampai ke daerah yang mengedepankan kemitraan, akan lebih efektif dari pada mengedepankan ego sektoral, karena seperti dalam pengertiannya kemitraan berarti membangun dan membina rasa saling percaya antar sektor.

b. Minimnya Alokasi Anggaran untuk Program Kerja TPPO

Sejalan dengan penanganan berbasis kinerja, maka pendanaan perlu mendukung upaya pemberantasan dan pencegahan tindak pidana perdagangan orang/anak untuk mendapatkan alokasi APBN yang memadai, namun juga tidak tertutup Dana tersebut terbatas untuk 
melaksanakan rapat-rapat koordinasi di tingkat Pusat dan Daerah. Untuk pengembangan secara lebih luas agar bisa menjangkau seluruh Provinsi dan Kabupaten/Kota serta seluruh fasilitas kesehatan diperlukan dukungan dana APBN dekonsentrasi.

Faktor anggaran menjadi hal yang sangat penting karena suatu hal yang tidak mungkin dalam melaksanakan program-program dan kegiatan tanpa anggaran tersendiri, meskipun bisa dilakukan namun sudah dapat dipastikan tidak akan maksimal. Dari segi implementasi di setiap lini, dan undang-undang harusnya diawasi oleh Binapenta (Kementrian Tenaga Kerja). Gugus tugas saat ini masih bersifat koordinatif, non anggaran dan tanpa program. Secara normatif Polri hanya melakukan penyidikan terkait laporan Polisi yang masuk terkait TPPO.

c. Alokasi Waktu Pertemuan AntarAnggota Gugus Tugas Tidak Maksimal

Pertemuan para anggota gugus tugas untuk koordinasi pada mulanya direncanakan secara berkala yaitu sekurang-kurangnya 6 bulan sekali apabila ada permasalahan yang dianggap besar dan urgen misalnya pemulangan besar-besaran (deportasi). Rapat koordinasi nasional (Rakornas) dilakukan secara berkala minimal sekali dalam satu tahun, demikian juga rapat koordinasi tingkat menteri. Sedangkan untuk Rakornas tingkat eselon I dan eselon II dilakukan minimal sekali dalam tiga bulan. Gugus Tugas Pusat PPTPPO secara berkala mengadakan Rakornas sekali dalam setaun untuk mengevakuasi perkembangan dan pelaksanaan

PPTPPO. Namun pada pelaksanaannya tidak dilakukan secara berkala. Perlunya memaksimalkan pertemuan guna membahas permasalahan yang dihadapi Tupoksi dan mencari jalan keluarnya. Selama ini banyak pertemuan yang membahas apa yang sudah dilakukan dan hanya bersifat sosialisasi. (Sutarman, 2014)

d. Kurangnya Sosialisasi di Tingkat Pemangku Kepentingan Tingkat Pusat dan Daerah.

Kurangnya sosialisasi di tingkat pemangku kepentingan tingkat pusat dan daerah menyebabkan tumpang tindih peraturan tentang TPPO, sehingga menyebabkan perbedaan persepsi antara pemangku kepentingan tingkat pusat dan daerah, maupun aparat penegak hukum dan anggota gugus tugas dalam melakukan upaya pencegahan dan penanganan kasus perdagangan orang (human trafficking), sehingga pelaksanaan dilapangannya kurang maksimal.

Perbedaan persepsi antar anggota gugus tugas, unsur CJS (Criminal Justice System) dan para stakeholder lainnya terkait dengan perdagangan orang. Perbedaan persepsi ini merupakan kendala yang paling terlihat dalam upaya pencegahan dan penanganan kejahatan perdagangan orang. Kendala yang dihadapi terletak pada tataran implementasi pada tiap sektor yang ada sehingga mengakibatkan efektivitas pencegahan dan penanganan yang dilaksanakan oleh Gugus Tugas tersebut tidak terwujud. 
e. Sumber Daya Manusia (SDM) yang Masih Kurang Memadai

Dalam menjalankan tugas dan fungsinya untuk mencegah dan menangani kasus tindak pidana perdagangan orang (TPPO), gugus tugas mengalami beberapa kendala, salah satu diantaranya ialah keterbatasan sumber daya manusia baik secara kuantitas maupun kualitas yang sangat mempengaruhi efektifitas gugus tugas dalam memberantas perdagangan orang (human trafficking).

Beberapa masalah yang menghambat dalam faktor sumber daya manusia antara lain: (1) Kurang ahlinya dan kurang pahamnya anggota gugus tugas dalam hal tindak pidana perdagangan orang;

Pemahaman tentang Tindak Pidana Perdagangan antar anggota gugus tugas sehingga koordinasi antara instansi cukup kompleks; (3) Kemajuan teknologi dalam sindikat perdagangan orang yang tidak diimbangi dengan kompetensi gugus tugas di bidang teknologi.

Dalam upaya pemberantasan dan pencegahan tindak pidana perdagangan orang/anak, peningkatan kapasitas sumber daya manusia harus dilakukan baik dari segi kuantitas maupun kualitas.

\section{Problematika Gugus Tugas dalam} Upaya Pencegahan dan Penanganan Kasus Ditinjau dari Faktor Eksternal

\section{a. Pemahaman dan Kesadaran Masyarakat tentang Bahaya Perdagangan Orang/Anak Masih Rendah}

Penanggulangan perdagangan orang itu tidak mudah, karena legitimasi masyarakat yang kuat mementingkan ekonomi keluarga dari pada takut akan hukum dan penyakit menular, karena itu semua informan sepakat bahwa pendekatan perdagangan orang harus melalui pendekatan komprehensif yaitu penegakan hukum dan penguatan kapasitas masyarakat. (Nuryani, 2012)

b. Kemajuan Teknologi dan Informasi yang Disalahgunakan

Sasaran pelaku human trafficking adalah dunia online yang banyak diakses oleh calon korban potensial. Kebanyakan dari calon korban potensial itu adalah anak-anak dan remaja pemilik akun media sosial yang mereka operasikan sendiri. Teknologi yang banyak digunakan sehari-hari oleh remaja meliputi Facebook, Twitter, Instagram, Skype, WhatsApp, Face time, Path, dan Line merupakan pintu masuk yang paling mudah untuk merekrut mereka menjadi korban Human Trafficking. Selain itu melalui media-media tersebut informasi seperti pornografi dan relasi pertemanan buta juga semakin mudah terakses. (Nadeak, 2019)

Informasi yang disampaikan oleh mtvexit.org menunjukkan bahwa rekrutmen Human Trafficking saat ini mulai memikat remaja calon korban melalui media online. Bahkan sekitar seperempat dari anak-anak yang dilaporkan hilang di Indonesia diyakini telah diculik dan mereka bertemu dengan si penculik melalui Facebook. Di Amerika serikat, pelaku seks komersial menggunakan situs-situs seperti Craigslist untuk merekrut dan menjual anak-anak dan remaja. (Ali, Mahrus, dan Pramono, 2011) 
c. Latar Pendidikan Korban yang Kurang mengenai Perdagangan Orang

Fakta menunjukan bahwa adanya suatu korelasi yang kuat antara perdagangan orang dengan tingkat pendidikan yang rendah, pelatihan yang tidak cukup dan kurangnya kesempatan memperoleh pendidikan. Rendahnya pendidikan dapat membuat seseorang tidak memiliki keterampilan (skill) yang dapat menunjang hidupnya kelak dan juga membuat seseorang memiliki pola pikir pendek, yang hanya memikirkan materi saja tanpa mempedulikan hal lain. Contohnya adalah sering orang tua beranggapan bahwa pendidikan itu tidak perlu, karena tidak akan menghasilkan materi. Kurangnya pendidikan yang diraih oleh orang tua korban dan korban yang membuat orang tua korban dan korban tidak bisa membaca dan memahami isi kontrak yang ditawarkan oleh pelaku. (Hanim \& Prakoso, 2015)

Legal Advisor dari Lembaga Amerika Serikat yang konsentrasi atas persoalan human trafficking, Terry Kinney menjelaskan bahwa bencana alam, tingkat pendidikan yang rendah, dan ketiadaan kemampuan atau keterampilan hidup adalah salah faktor yang mempengaruhi korban untuk terjerat dalam lingkaran kejahatan perdagangan manusia. Pada beberapa kasus, para pelaku human trafficking bertindak seolah-olah sebagai agen penyalur tenaga kerja yang akan menyalurkan para tenaga kerja pada perusahaan tertentu di luar negeri. (Aisyah, 2012) d. Korban Tidak Mau Melapor

Adapun penyebab lain yang membuat korban enggan melapor adalah takut akan mendapatkan kesulitan saat akan mengajukan tuntutan karena belum merasa terlindungi dan merasa saat dilakukan pemeriksaan bukan seperti korban tetapi pelaku sehingga korban merasa tidak mempunyai hak untuk mengeluarkan pendapat dan terintimidasi oleh keadaan. Korban merasa tidak mempunyai pendukung untuk menuntut keadilan. Kejahatan perdagangan orang (human trafficking) adalah kejahatan yang cukup sulit dideteksi, dengan tidak adanya laporan dari korban maka akan menjadi problematika bagi gugus tugas untuk mendeteksi dan memberantas sindikat kejahatan perdagangan orang.

e. Implementasi Kebijakan mengenai Tindak Pidana Perdagangan Orang yang Belum Optimal.

Implementasi UU No. 21 Tahun 2007 terkendala karena masih sering diterapkannya UU No. 23 Tahun 2002 dalam menyelesaikan kasus perdagangan perempuan dan anak. Dampaknya sanksi yang dijatuhkan sangat ringan dan korban tidak mendapatkan hak restitusi. Disamping itu kesulitan yang sering ditemui di dalam penanganan tindak pidana perdagangan orang adalah dalam mengungkapkan pembuktian yang menunjukkan terjadinya perdagangan perempuan dan anak sebagaimana diatur dalam UU No. 21 Tahun 2007. 
f. Pola Perdagangan Manusia Sangat Bervariasi dari Satu Tempat ke Tempat Lainnya.

Pola perdagangan manusia sangat bervariasi dari satu tempat ke tempat lainnya, namun ada beberapa karakteristik pokok pola perdagangan manusia yang terjadi yaitu: (1) Perdagangan manusia terjadi baik di dalam atau di luar negara; (2) Perdagangan manusia terjadi untuk berbagai tujuan akhir seperti, pembantu rumah tangga, dan sebagainya; (3) Kebanyakan pelaku perdagangan memakai berbagai kecurangan atau penipuan guna menjalin kerjasama dengan orang yang mengalami Trafficking; (4) Orang yang mengalami perdagangan manusia biasanya sulit untuk melepaskan diri dari jeratan itu; (5) Pelaku perdagangan manusia banyak menggunakan berbagai cara rekruitmen; (6) Perdagangan manusia semakin marak dikarenakan korupsi sektor publik; (7) Korban perdagangan manusia yang dikirim ke luar negeri dengan cara yang illegal (Mareta, 2017).

\section{Simpulan dan Saran}

Ditinjau dari faktor internal, problematika Gugus Tugas dalam upaya pencegahan dan penanganan kasus perdagangan orang (Human Trafficking) meliputi: (1) koordinasi antar instansi yang belum optimal; (2) minimnya alokasi anggaran untuk program kerja TPPO; (3) alokasi waktu pertemuan antar anggota gugus tugas tidak maksimal; (4) kurangnya sosialisasi di tingkat pemangku kepentingan tingkat pusat dan daerah menyebabkan tumpang tindih peraturan tentang TPPO; (5) sumber daya manusia yang masih kurang memadai.

Problematika gugus tugas dalam upaya pencegahan dan penanganan kasus perdagangan orang (human trafficking) ditinjau dari faktor eksternal yaitu: (1) pemahaman dan kesadaran masyarakat tentang bahaya perdagangan orang/anak masih rendah; (2) kemajuan teknologi dan informasi yang disalahgunakan; (3) latar pendidikan korban yang kurang mengenai perdagangan orang; (4) korban tidak mau melapor; (5) implementasi kebijakan mengenai tindak pidana perdagangan orang yang belum optimal; (6) pola perdagangan manusia sangat bervariasi dari satu tempat ke tempat lainnya.

Kesimpulan pada penelitian ini ialah bahwa gugus tugas memiliki problematika yang berbeda apabila ditinjau dari faktor internal maupun faktor eksternal sehingga pada tiap-tiap permasalahan dibutuhkan penanganan dan solusi yang berbeda sehingga peran gugus tugas dapat berjalan dengan optimal.

Solusi yang tepat dalam menangani problematika internal ialah melalui koordinasi antar instansi untuk menyatukan visi dan misi gugus tugas dalam memberantas tindak pidana perdagangan orang sehingga tidak ada tumpang tindih dalam melaksanakan tugas dan fungsi masing-masing anggota gugus tugas, menyusun proposal rancangan program kerja dan alokasi anggaran yang dibutuhkan untuk penanganan TPPO, update sumber daya manusia melalui rapat koordinasi, pendidikan dan latihan (Diklat).

Solusi dalam menangani problematika eksternal ialah melalui beberapa cara yaitu sosialisasi kepada masyarakat mengenai perdagangan orang, technology protect untuk mengawasi indikasi perdagangan orang melalui media sosial (internet), menyediakan layanan cepat tanggap yang secara khusus menangani kasus perdagangan orang, evaluasi implementasi kebijakan mengenai tindak pidana perdagangan orang, pertukaran informasi atau kunjungan study ke berbagai negara terkait kasus perdagangan orang dan bagaimana penanganannya di tiap-tiap negara tersebut. 


\section{DAFTAR PUSTAKA}

Affairs, M. of F. (2012). National Plan of Action Against Trafficking in Persons 2012 to 2015. Affairs, Ministry of Foreign.

Aisyah, A. (2012). Pendidikan Minim Jerat Korban Human Trafficking. news.okezone.com.

https://news.okezone.com/read/2012/10/ 12/373/703154/pendidikan-minim-jeratkorban-human-trafficking

Ali, Mahrus, dan Pramono, B. A. (2011). Perdagangan Orang: Dimensi; Instrumen Internasional dan Pengaturannya Di Indonesia (C. A. Bakti (ed.); 1 ed.). Citra Aditya Bakti.

Ali, Z. (2011). Metode Penelitian Hukum (A. Zainuddin (ed.); 1 ed.). Sinar Grafika.

Anil Kumar, J. (2018). The Impact of Human Trafficking in ASEAN: Singapore as a Case-Study. Asian Journal of International Law, 8, 189224.

https://doi.org/doi:10.1017/S204425131 6000254

Arikunto, S. (2012). Prosedur Penelitian Suatu Pendekatan Praktek (S. Arikunto (ed.); 6 ed.). Rineka Cipta.

Erdianto, E. (2013). Pemberantasan Perdagangan Orang Dengan Sarana Hukum Pidana. Cita Hukum, 1, 87. https://media.neliti.com/media/publicati ons/40856-ID-pemberantasanperdagangan-orang-dengan-saranahukum-pidana.pdf

Han, L. Y. (2014). "Parliament: Tragic Stories of Human Trafficking in Modern Singapore" The Straits Times. The Straits Times. https://www.asiaone.com/singapore/parl iament-tragic-stories-human-traffickingmodern-singapore

Hanim, L., \& Prakoso, A. P. (2015). Perlindungan Hukum Terhadap Korban
Kejahatan Perdagangan Orang (Studi Tentang Implementasi Undang-Undang No. 21 Tahun 2007). Jurnal: Pembaharuan Hukum, II, 236-238. http://jurnal.unissula.ac.id/index.php/PH /article/viewFile/1434/1107

Undang-Undang Nomor 21 Tahun 2007 Tentang Pemberantasan Tindak Pidana Perdagangan Orang, Pub. L. No. Nomor 21 (2007). https://pih.kemlu.go.id/files/UU_no_21 th_2007 tindak pidana perdagangan orang.pdf

Indrawati. (2015). Trafficking Kejahatan Terhadap Perempuan dan Anak-Anak. Jurnal Cakrawala Hukum, 6, 36-44. http://jurnal.unmer.ac.id/index.php/jch/a rticle/view/683

Lembaga, B. P. H. N. (2011). Koordinasi Antar Lembaga dalam Pemberantasan Perdagangan Anak. www.bphn.go.id. https://www.bphn.go.id/data/documents /koordinasi_antar_lembaga_dalam_pem berantasan_perdagangan_anak.pdf

Mareta, F. A. (2017). Upaya Perlindungan Hukum Bagi Korban Tindak Pidana Perdagangan Anak Di Surakarta. Skripsi Program Studi Ilmu Hukum Fakultas Hukum Universitas Muhammadiyah Surakarta, 8. http://eprints.ums.ac.id/51475/

Nadeak, H. (2019). Kajian Hukum Terhadap Tindak Pidana Perdagangan Orang Melalui Media Sosial (Studi Putusan Nomor 388/Pid.Sus/2018/PN.Mdn) [Universitas Medan Area]. http://repository.uma.ac.id/bitstream/12 3456789/10846/2/158400023 - Herman Nadeak - Fulltext.pdf

Nugroho, O. C. (2018). Tanggung Jawab Negara Dalam Penanganan Tindak Pidana Perdagangan Orang (State's Responsibility in Mitigation of Human Trafficking Crime). Jurnal: Penelitian Hukum DE JURE, 18, 543-560. https://doi.org/http://dx.doi.org/10.3064 1/dejure.2018.V18.543-560 
Nuryani, Y. (2012). Pencegahan Kejahatan Perdagangan Orang Secara Terpadu (Studi Tentang Efektifitas Gugus Tugas Pencegahan Dan Penanganan TPPO) [Universitas Indonesia]. http://lib.ui.ac.id/file?file=digital/20306 171-T30974 - Pencegahan kejahatan.pdf

Prakoso, Abdul Rahman, \& Nurmalinda, P. A. (2018). Kebijakan Hukum Terhadap Tindak Pidana Perdagangan Orang. Seminar Nasional Hukum Universitas Negeri Semarang, 4, 1-24. http://badiklat.kejaksaan.go.id/eakademik/uploads/bahan_ajar/bbb89b85 5fdfde8b74e478c7e1884b59.pdf

Pusat Bahasa, \& Departemen Pendidikan Nasional. (2008). Kamus Besar Bahasa Indonesia (D. Sugono (ed.); 4 ed.). Pusat Bahasa.

https://bahasawan.id/t/tempatmengunduh-kbbi-pdf-luring-downloadkbbi-offline-lengkap/438

Saputra, I. Y. (2019). Miris, Perdagangan
Anak di Semarang Naik Tajam di 2018. semarang.solopos.com.

https://www.solopos.com/mirisperdagangan-anak-di-semarang-naiktajam-di-2018-976706

Shelley, L. (2010). Human Trafficking: A Global Perspective. The United States of America by Cambridge University Press, New York. https://doi.org/https://doi.org/10.1017/C BO9780511760433

Soekanto, S. dan S. M. (2009). Penelitian Hukum Normatif (S. Soekanto (ed.); 8 ed.). Raja Grafindo Persada.

Sutarman, H. (2014). Efektivitas Gugus Tugas Dalam Melaksanakan PERDA Provinsi Kalbar Nomor 7 Tahun 2007 Tentang Pencegahan Dan Pemberantasan Perdagangan Orang Terutama Perempuan dan Anak. Jurnal: Nestor Fakultas Hukum Untan, 3. http://jurnal.untan.ac.id/index.php/jmfh/ article/view/12228 